\title{
Antitumor Effects of Eubacterium Lentum Fractions and Its Correlation with the Macrophages, Natural Killer Activities in Mice
}

Mochammad Hatta

\begin{abstract}
Abstrak
Dilakukan penelitian terhadap pengaruh fraksi sel dari Eubacterium lentum, terutama pengaruh dinding sel dan fraksi 2 (membran sitoplasma) terhadap "Ehrlich ascites tumor bearing mice". Semua fraksi kecuali dinding sel dan fraksi 2 tidak efektif dalam menghambat pertumbuhan "Ehrlich ascites tumor" pada mencit ICR. Injeksi intratumor dinding sel Eubacterium lentum dengan dosis sekurangkurangnya $100 \mu \mathrm{g}$ secara bermakna menghambat pertumbuhan sel tumor pada hari ke 21 setelah inokulasi sel tumor dan inemperpanjang "Survival time" mencit. Injeksi intravena dinding sel dengan dosis sekurang-kurangnya $200 \mu$ g efekrif dalam memperpanjang "survival time" dari "tumor bearing mice". Selanjutnya diperiksa pula pengaruh pemberian dinding sel dan fraksi 2 secara intraperitonium terhadap aktivitas makrofag dari cairan peritoneum. Hasil yang didapatkan menunjukkan bahwa baik dinding sel maupun fraksi 2 mempunyai kemampuan untuk meningkatkan aktivitas makrofag dari cairan peritoneum pada mencit Balb/c. Disamping itu diteliti "cell mediated cytotoxicity" pada level sel tunggal terhadap YAC-1 lymphoma sebagai sel target dengan pemberian dinding sel atau fraksi 2 dan kinetik dari aktivitas sel "natural killer" limpa. Hasil tersebut menunjukkan bahwa baik dinding sel maupun fraksi 2 merupakan aktivator yang kuat dari sel "natural killer" limpa pada mencit $\mathrm{C}_{3} \mathrm{H} / \mathrm{He}$.
\end{abstract}

\begin{abstract}
The present study was undertaken to examine the effects of cell fractions of Eubacterium lentum, expecially cell wall and fraction 2 (cytoplasmic membrane) on Ehrlich ascites tumor-bearing mice. All fractions except cell wall and fraction 2 did not effectively inhibit the Ehrlich ascites tumor growth in ICR mice. Intratumoral injection of cell wall of Eubacterium lentum at a dose of at least $100 \mu \mathrm{g}$ significantly inhibited the tumor growth 21 days after tumor inoculating and prolonged the survival time of mice. Intravenous injection of cell wall at a dose of at least $200 \mu \mathrm{g}$ was effective in prolonging the survival time of tumor-bearing mice. Moreover, the effects of intraperitoneal treatment by cell wall or fraction 2 of Eubacterium lentum on macrophage activities of peritoneal exudate cavity (PEC) cells was examined. The results obtained showed that both cell wall and fraction 2 have the ability to enhance the peritoneal macrophage activity in Balb/c mice. Furthermore, cell mediated cytotoxicity at single cell levels against YAC-1 lymphoma as target cell when treated with cell wall or fraction 2 and the kinetics of natural killer $(N K)$ activity of spleen cells were observed. These results suggest that both cell wall and fraction 2 are potent activators of natural killer $(\mathrm{NK})$ of spleen cells in $\mathrm{C}_{3} \mathrm{H} / \mathrm{He}$ mice.
\end{abstract}

Key words : Antitumor, Eubacterium lentum fractions, Macrophage, Natural Killer

\section{INTRODUCTION}

Eubacterium lentum is an anaerobic gram positive short rod bacteria and a natural component of the human intestinal flora. The antitumor effects of Eubacterium lentum have been studied continously in experimental animals. ${ }^{1}$

Some basic effects of Eubacterium lentum on the immune system and its effects on various experimental tumor cell lines have been observed. Also, Eubacterium lentum has been shown to have indirect cytotoxic effects againts Ehrlich ascites tumor. ${ }^{2}$ Recently, a variety of immunomodulatory effects have been observed in tumor bearing hosts, following treatment with bacteria or bacterial products as biological response modifiers, but the mechanism by which these agents work is still unclear. Commonly, gram positive bacteria cell walls such as that of Bacillus cereus, Lactobacillus casei and Nocardia rubra have peptidoglycan compounds ${ }^{3,4,5,6}$ and antitumor effects in experimental animal systems.

Macrophages have multiple functions such as antineoplastic activity and regulation of immune responses. Some bacteria, such as Listeria monocytogenes 
and Mycobacterium tuberculosis have been shown to increase macrophage activity by in vivo treatment. ${ }^{7,8}$

Amongst the known cellullar effector mechanisms, natural killer (NK) cells mediated by large granular lymphocytes are thought to represent the first line of defence against cancer. ${ }^{9}$ The ability of some bacteria such as Streptococcus pyogenes, Lactobacillus casei, Mycobacterium tuberculosis, Bordetella pertusis, Nocardia rubra, Corynebacterium parvum and Propionebacterium acnes to augment NK cells, and induce various cytokines both in human and experimental animals has been reported. ${ }^{10,11,12,13,14,15,16}$

\section{MATERIALS AND METHODS}

Animals. Inbred male ICR mice, $\mathrm{C}_{3} \mathrm{H} / \mathrm{He}$ mice, Balb/c mice, 5 to 8 weeks old were purchased from Japan SLC Inc., Hamamatsu, Japan.

Tumor cell lines. The Ehrlich ascites tumor syngeneic to ICR mice were used for in vivo experiments. YAC-1 lymphoma, P-815 mastocytoma, EL-4 lymphoma used as target cells were maintained on continous in vitro culture in RPMI-1640 supplemented with $10 \%$ FCS, $100 \mathrm{U}$ pencillin $/ \mathrm{ml}, 100 \mathrm{~g} / \mathrm{ml}$ streptomycin and $2 \mathrm{mM}$ L-glutamine.

Preparation of Eubacterium lentum fractions. Eubacterium lentum (TYH-11) was obtained in our laboratory from normal human intestinal flora. The bacteria were grown in GAM broth medium (Nissui Co., Ltd.) overnight at $37^{\circ} \mathrm{C}$ under anaerobic condition. The cells collected by centrifugation at $8000 \mathrm{~g}$ for 30 minutes at $4^{\circ} \mathrm{C}$ were washed three times with sterile distilled water. The cells were suspended in distilled water and lyophilized.

Two g lyophilized Eubacterium lentum whole bodies were suspended in $100 \mathrm{ml}$ distilled water, dispersed in a sonicator for 15 minutes and disrupted in Homogenizer cells (Siber Kikai K.K., Japan) at 900 bar pressure.

The process was judged complete when more than $80 \%$ of non fragmented bacteria were seen in smears stained by the Gram method. The disruption product was centrifuged at $3000 \mathrm{~g}$ for 30 minutes to provide a supernatant. The sediment was suspended with distilled water and lyophilized to provide fraction 1 containing Eubacterium lentum whole body impurities. Then the supernatant was centrifuged at $20000 \mathrm{~g}$ for 1 hour to remove a sediment of "crude cell wall" and the supernatant was fraction 2, containing cytoplasmic membrane. "Crude cell wall" was treated by the method of Azuma, I. ${ }^{17}$

Briefly, $3 \mathrm{~g}$ of "crude cell wall" was suspended in $400 \mathrm{ml} \mathrm{0.07} \mathrm{M} \mathrm{phosphate} \mathrm{buffer} \mathrm{(} \mathrm{pH}$. 7.8) containing $10 \%$ each of trypsin and chymotrypsin. The suspension was gently stirred at room temperature for 24 hours and then centrifuged at $20000 \mathrm{~g}$ for 1 hour. The trypsin and chymotrypsin treatment was repeated and the supernatants provided fraction 3 and 4 containing the cell wall impurities and teichoic acid, respectively. The sediment was then suspended in $0.01 \mathrm{M}$ Tris $\mathrm{HCl}$-buffer (p.H 7.2) containing $10 \%$ pronase. After gentle agitation for 24 hours at room temperature, the suspension was centrifuged at $20000 \mathrm{~g}$ for 1 hour. This pronase treatment was repeated and supernatants were fraction 5 and 6 containing free lipids. The sediments were washed with Tris $\mathrm{HCl}$ buffer, $0.85 \% \mathrm{NaCl}$ in water, distilled water respectively and lyophilized to provide "pure cell wall" (cell wall fraction).

Antitumor activity in vivo. Ehrlich ascites tumor cells were suspended in RPMI-1640 supplemented with $10 \% \mathrm{FCS}$ and inoculated at $10^{5}$ cells/animal intraperitoneal (i.p.) or $10^{6}$ cells/animal subcutaneous (s.c.). Each fraction was injected intraperitoneally, intratumorally or intravenously for 7 days.

Survival mice were followed for 42 days for the intraperitoneal inoculation (ascites form) and 100 days for the subcutaneous inoculation (solid form) of Ehrlich ascites tumor.

Mean survival time was calculated using following formula :

MST $(\% \mathrm{~T} / \mathrm{C})=$ mean survival days of treated group/ control group $\mathrm{x} 100$.

Tumor weight was calculated using following formula: Tumor weight $(\mathrm{mg})=\left\{\right.$ major axis $\left.\mathrm{x}(\text { minor axis })^{2}\right\} / 2$.

Preparation of macrophages cytostasis assay.

$\mathrm{Balb} / \mathrm{c}$ mice were injected intraperitoneally with pure cell wall or fraction 2 for 7 days and peritoneal exudate cavity (PEC) cells were obtained on day 14 . The PEC cells were collected by washing the peritoneal cavity of mice with $2.5 \mathrm{ml}$ Hank's balance salt solution (HBSS) and centrifuged at $800 \mathrm{~g}$ for 10 minutes. The PEC suspension was incubated in a plastic dishes at $37^{\circ} \mathrm{C}$ for 90 minutes and plastic adherent cells were used as effector cells. Suspension of effector cells were added to triplicate wells to give effector target ratio 10 $: 1$ or $5: 1$. The macrophages cytostasis assay was performed in 96 well microtiter using ${ }^{51} \mathrm{Cr}$ prelabeled target. The assay plates were incubated 20 hours at $37^{\circ} \mathrm{C}$ in a humidified $\mathrm{CO}_{2}$ incubation. After incubation, the percentage of specific ${ }^{5 !} \mathrm{Cr}$ release was calculated using a gamma counter.

Preparation of cytotoxic assay. $\mathrm{C}_{3} \mathrm{H} / \mathrm{He}$ mice were injected with pure cell wall or fraction 2 and spleens were aseptically removed, and single cell suspension were prepared in RPMI-1640 supplemented with $10 \%$ FCS. $100 \mu \mathrm{g} / \mathrm{ml}$ penicillin $\mathrm{G}$, and $100 \mu \mathrm{g} / \mathrm{ml}$ streptomycin. Splenic mononuclear cells were treated 
with $\mathrm{KAC}-2$ to remove monocytes/macrophages. The mononuclear cells were obtained after centrifugation on Ficoll-Hypaque gradients (density $=1.007$ ) at 3000 rpm for 30 minutes, and cells were collected, washed and used as effector cells.

Cytotoxicity was measured in standard $4 \mathrm{~h}{ }^{51} \mathrm{Cr}$ release microcytotoxicity assay using $96-$ well round bottomed microplates (Costar, Cambride, MA). YAC$1\left(2 \times 10^{5}\right.$ cells/well $)$ as target cells were labeled by incubation with $100 \mathrm{uCi} \mathrm{Na}{ }^{51} \mathrm{C}_{\mathrm{T}} \mathrm{O}_{4}$ for 1 hour at $37^{\circ} \mathrm{C}$ in a shaking water bath. After incubation, the cells were washed three times with HBSS to remove unbound radio label. Suspension of effector cells was added to triplicate wells to give an effector target ratio of $50: 1$ or $25: 1$. After an additional incubation at $37^{\circ} \mathrm{C}$ for 4 hours, each well was counted in a gamma counter to determine experimental release (ER). Spontaneous release (SR) was obtained from wells receiving target cells and medium only, and total release (TR) was obtained from wells receiving $1 \%$ Triton $\mathrm{X}-100$.

The percentage of cytotoxicity was calculated by following formula :

$\%$ of cytotoxicity $=\{($ ER $)-($ SR $)\} /\{($ TR $)-($ SR $)\} \times 100$.

\section{RESULTS}

Effects of intraperitoneal (i.p.) injection of Eubacterium lentum fractions on ascites form of Ehrlich ascites tumor.

To determine antitumor effects of Eubacterium lentum fractions, ICR mice were inoculated intraperitoneally with $10^{5}$ cells/mice of ascites form of Ehrlich ascites tumor and injected i.p. with Eubacterium lentum or Eubacterium lentum fractions for 7 days (table 1). All control animals died of progressive tumor growth in the peritoneal cavity on day 17 after tumor inoculation. Mean survival time of the Eubacterium lentum group, the fraction 2 group and the cell wall fraction group (26,22 and 22 days respectively), were all longer than that of the control group. No significant antitumor effects were shown by the other fraction groups.

Effects of intratumoral (i.t). injection of Eubacterium lentum fractions on solid form of Ehrlich ascites tumor.

The i.t. treatment with Eubacterium lentum, fraction 2 and cell wall fraction slightly prolonged the survival time and significantly suppressed the tumor weight on day 21 as compared to the control group (table 2). The mean tumor weight $(\% \mathrm{~T} / \mathrm{C})$ of these three groups were
$31.2 \%, 25.2 \%$ and $27.6 \%$ respectively. In contrast no antitumor activities were observed in the other fraction groups.

Table 1. Effects of intraperitoneal injection of Eubacterium lentum fractions on Ehrlich ascites tumor

\begin{tabular}{llc}
\hline Treatment $^{\mathrm{a})}$ & MST $^{\mathrm{b})}$ & \% survival \\
\hline control (untreated) & $17.3 \pm 0.8$ & 100 \\
Eubacterium lentum $^{\mathrm{c})}$ & $26.7 \pm 2.8^{\star}$ & 154 \\
fraction $1(216 \mu \mathrm{g})^{\mathrm{d})}$ & $15.8 \pm 3.1$ & 91 \\
$2(1080 \mu \mathrm{g})$ & $22.2 \pm 0.9^{\star \star}$ & 128 \\
$3(1833 \mu \mathrm{g})$ & $18.5 \pm 1.8$ & 128 \\
$4(1578 \mu \mathrm{g})$ & $20.8 \pm 2.8$ & 121 \\
$5(819 \mu \mathrm{g})$ & $18.6 \pm 1.5$ & 108 \\
$6(780 \mu \mathrm{g})$ & $20.6 \pm 2.8$ & 119 \\
cell wall $(300 \mu \mathrm{g})^{\mathrm{e})}$ & $22.0 \pm 1.7^{\star \star}$ & 125 \\
\hline
\end{tabular}

a) Ehrlich ascites tumor cells $\left(10^{5}\right.$ cells/mouse $)$ inoculated into ICR mice ( 10 mice/group) intraperitoneally (i.p.) on day $O$.

b) mean survival time (days) indicates the mean \pm standard deviation.

c) Eubacterium lentum ( $10^{7}$ cells/mouse) injected i.p. for 7 days.

d) Each fraction injected i.p. for 7 days.

e) pure cell wall injected i.p. for 7 days. Statistical significance of difference from untreated control ${ }^{*} \mathrm{p}<0.01 \quad{ }^{*} \mathrm{p}<0.05$.

Table 2. Effects of intratumoral injection of Eubacterium lentum fractions on Ehrlich ascites tumor.

\begin{tabular}{|c|c|c|c|c|}
\hline \multicolumn{2}{|c|}{ Treatment $^{a)}$} & $\begin{array}{c}\text { MST } \\
(\% \mathrm{~T} / \mathrm{C})^{\mathrm{b})}\end{array}$ & $\begin{array}{l}\text { no.survival mice } \\
\text { no.tesled mice } \\
\text { () cured mice }\end{array}$ & $\begin{array}{c}\text { tumor weight } \\
\text { on day } 21(\mathrm{~g}) \\
(\% \mathrm{~T} / \mathrm{C})^{\mathrm{c})}\end{array}$ \\
\hline \multirow{2}{*}{\multicolumn{2}{|c|}{$\begin{array}{l}\text { control (untreated) } \\
\text { Eubacterium lentum d) }\end{array}$}} & 100 & $0 / 10$ & 100 \\
\hline & & 147.2 & $1 / 10(1)$ & $31.2^{\star}$ \\
\hline \multirow[t]{6}{*}{ fraction } & $\left.1(216 \mu g)^{c}\right)$ & 106.7 & $0 / 10$ & 76.6 \\
\hline & $2(1080 \mu \mathrm{g})$ & 122.5 & $2 / 10(2)$ & $25.2^{\star}$ \\
\hline & $3(1833 \mu \mathrm{g})$ & 127 & $0 / 10$ & 75.4 \\
\hline & $4(1578 \mu \mathrm{g})$ & 110.1 & $0 / 10$ & 124.9 \\
\hline & $5(819 \mu \mathrm{g})$ & 116.9 & $0 / 10$ & 104.7 \\
\hline & $6(780 \mu \mathrm{g})$ & 100 & $0 / 10$ & 96.4 \\
\hline cell wall & $(300 \mu g)^{\sigma}$ & 112.4 & $2 / 10(1)$ & $27.6^{*}$ \\
\hline
\end{tabular}

a) Ehrlich ascites tumor cells ( $10^{6}$ cells/mouse) inoculated into ICR mice (10 mice/group) subcutaneously (s.c.) on day O.

b) survival time $(\% \mathrm{~T} / \mathrm{C})$ indicates the mean tested/control group $x 100$.

c) tumor weight $(\% \mathrm{~T} / \mathrm{C})$ indicates the mean tested/control group $\mathrm{x} \mathbf{1 0 0}$.

d) Eubacterium lentum ( $10^{7}$ cells/mouse) injected intratumorally (i.t) for 7 days.

e) Each fraction injected i.t. for 7 days.

f) pure cell wall injected i.t. for 7 days. Statistical significance of difference from untreated control ${ }^{*} \mathrm{p}<0.01$. 
Effects of intravenous (i.v.) injection of Eubacterium lentum fractions on solid form of Ehrlich ascites tumor.

After multiple treatments with Eubacterium lentum, fraction 2 and cell wall, the tumor weights on day 21 were significantly lower than that of the control group (table 3 ). The mean tumor weight (\% T/C) of these three groups were $16.4 \%, 31.7 \%$ and $47.1 \%$ respectively. The survival times of mice receiving Eubacterium lentum, fraction 2 and cell wall were slightly prolonged. In the other fractions no antitumor effects were seen.

Table 3. Effects of intravenous injection of Eubacterium lentum fractions on Ehrlich ascites tumor.

\begin{tabular}{|c|c|c|c|c|}
\hline \multicolumn{2}{|c|}{ Treatment ${ }^{a)}$} & $\begin{array}{c}\text { MST } \\
(\% \mathrm{~T} / \mathrm{C})^{\mathrm{b})}\end{array}$ & $\begin{array}{l}\text { no.survival mice/ } \\
\text { no.lested mice } \\
\text { () cured mice }\end{array}$ & $\begin{array}{c}\text { tumor weight } \\
\text { on day } 21(\mathrm{~g}) \\
\left.(\% \mathrm{~T} / \mathrm{C})^{\mathrm{c}}\right)\end{array}$ \\
\hline \multirow{2}{*}{\multicolumn{2}{|c|}{$\begin{array}{l}\text { control (untreated) } \\
\text { Eubacterium lentum d) }\end{array}$}} & 100 & $0 / 10$ & 100 \\
\hline & & 130.3 & $3 / 10(3)$ & $16.4^{*}$ \\
\hline \multirow[t]{6}{*}{ fraction } & $1(216 \mu \mathrm{g})^{\mathrm{e})}$ & 108.9 & $0 / 9$ & 93.3 \\
\hline & $2(1080 \mu \mathrm{g})$ & 128 & $2 / 10$ & $31.7^{*}$ \\
\hline & $3(1833 \mu \mathrm{g})$ & 85.7 & $0 / 10$ & 164.6 \\
\hline & $4(1578 \mu \mathrm{g})$ & 93.8 & $0 / 10$ & 106.5 \\
\hline & $5(819 \mu \mathrm{g})$ & 98.1 & $0 / 10$ & 88.5 \\
\hline & $6(780 \mu \mathrm{g})$ & 83.9 & $0 / 10$ & 104.7 \\
\hline \multicolumn{2}{|c|}{ cell wall $(300 \mu \mathrm{g})^{\mathrm{f})}$} & $195.5^{\star}$ & $2 / 10$ & $47.1^{\star}$ \\
\hline
\end{tabular}

a) Ehrlich ascites tumor cells ( $10^{6}$ cells/mouse) inoculated into ICR mice subcutaneously (s.c.) on day $O$.

b) survival time $(\% \mathrm{~T} / \mathrm{C})$ indicates the mean tested/control group $\mathrm{x} 100$.

c) tumor weight $(\% \mathrm{~T} / \mathrm{C})$ indicates the mean tested/control group $x 100$

d) Eubacterium lentum ( $10^{7}$ cells/mouse) injected intravenously (i.v) for 7 days.

e) Each fraction injected i.v. for 7 days.

f) pure cell wall injected i.v. for 7 days.

Statistical significance of difference from untreated control ${ }^{*} \mathrm{p}<0.01$.

\section{Effects of local injection of various doses of cell wall on tumor growth}

Various doses $(50 \mu \mathrm{g}$ to $1000 \mu \mathrm{g})$ of cell wall fractions were examined for the effects of their intratumoral (i.t.) injection on tumor growth (table 4). Doses of $100 \mu \mathrm{g}$ to $1000 \mu \mathrm{g}$ significantly inhibited the tumor growth on day 21 . Mice treated with a dose of $1000 \mu \mathrm{g}$ cell wall caused clear inhibition of tumor growth and prolonged the survival time of tumor-bearing mice (two fold in comparison with the control group); there was a complete cure in 2 of 9 tested mice.
Table 4. Effects of intratumoral injection of various doses of pure cell wall on Ehrlich ascites tumor

\begin{tabular}{|c|c|c|c|}
\hline Treatment $^{a)}$ & $\begin{array}{c}\text { MST } \\
(\% \mathrm{~T} / \mathrm{C})^{\mathrm{b})}\end{array}$ & $\begin{array}{l}\text { no.survival mice/ } \\
\text { no.tested mice } \\
\text { () cured mice }\end{array}$ & $\begin{array}{l}\text { tumor weight } \\
\text { on day } 21(\mathrm{~g}) \\
(\% \mathrm{~T} / \mathrm{C})^{\mathrm{c})}\end{array}$ \\
\hline control (untreated) & 100 & $0 / 10$ & 100 \\
\hline cell wall $(50 \mu \mathrm{g})^{\mathrm{d})}$ & 130.6 & $0 / 10$ & 45.3 \\
\hline$(100 \mu \mathrm{g})$ & $162^{* \star}$ & $1 / 10$ & $34.0^{\star *}$ \\
\hline$(200 \mu \mathrm{g})$ & $212.5^{*}$ & $3 / 8(1)$ & $32.5^{\star \star}$ \\
\hline$(300 \mu \mathrm{g})$ & $169.4^{\star *}$ & $0 / 10$ & $35.8^{* *}$ \\
\hline$(500 \mu \mathrm{g})$ & $197.2^{\star}$ & $2 / 10(1)$ & $18.4^{\star}$ \\
\hline$(800 \mu \mathrm{g})$ & $213.9^{*}$ & $0 / 10$ & $19.8^{*}$ \\
\hline$(1000 \mu \mathrm{g})$ & $222.2^{\star}$ & $2 / 9(2)$ & 15.9 \\
\hline
\end{tabular}

a) Ehrlich ascites tumor cells ( $10^{6}$ cells/mouse) inoculated into ICR mice subcutaneously (s.c.) on day O.

b) survival time $(\% \mathrm{~T} / \mathrm{C})$ indicates the mean tested/control group $\mathrm{x} 100$.

c) tumor weight $(\% \mathrm{~T} / \mathrm{C})$ indicates the mean tested/control group $x 100$.

d) various doses of pure cell wall injected intratumorally (i.t.) for 7 days.

Statistical significance of difference from untreated control ${ }^{\star} \mathrm{p}<0.01 \quad * \star \mathrm{p}<0.05$.

Effects of systemic injection of various doses of cell wall on tumor growth

Cell wall i.v. injected at a dose of at least $200 \mu \mathrm{g}$ significantly inhibited the tumor growth on day 21 and prolonged the survival time (table 5). Cell wall at the doses of $200 \mu \mathrm{g}$ and $500 \mu \mathrm{g}$ completely cured 1 of 11 tested mice and 3 of 7 tested mice respectively.

Table 5. Effects of intravenous injection of various doses of pure cell wall on Ehrlich ascites tumor.

\begin{tabular}{|c|c|c|c|}
\hline Treatment ${ }^{a)}$ & $\begin{array}{c}\text { MST } \\
(\% \mathrm{~T} / \mathrm{C})^{\mathrm{b})}\end{array}$ & $\begin{array}{l}\text { no.survival mice/ } \\
\text { no.tested mice } \\
\text { ( ) cured mice }\end{array}$ & $\begin{array}{c}\text { tumor weight } \\
\text { on day } 21(\mathrm{~g}) \\
(\% \mathrm{~T} / \mathrm{C})^{\mathrm{c})}\end{array}$ \\
\hline control (untreated) & 100 & $0 / 10$ & 100 \\
\hline cell wall $(50 \mu \mathrm{g})$ & 73.8 & $0 / 10$ & 128.7 \\
\hline$(100 \mu \mathrm{g})$ & 87.3 & $0 / 10$ & 104.1 \\
\hline$(200 \mu \mathrm{g})$ & $173^{*+}$ & $1 / 11(1)$ & $77.4^{\star \star}$ \\
\hline$(300 \mu \mathrm{g})$ & $195.5^{\star}$ & $2 / 10$ & $47.1^{*}$ \\
\hline$(500 \mu \mathrm{g})$ & $229.2^{\star}$ & $3 / 7(3)$ & $38.8^{*}$ \\
\hline
\end{tabular}

a) Ehrlich ascites tumor cells $\left(10^{6}\right.$ cells/mouse $)$ inoculated into ICR mice subcutaneously (s.c.) on day $O$.

b) survival time (\%T/C) indicates the mean tested/control group $x 100$.

c) tumor weight $(\% \mathrm{~T} / \mathrm{C})$ indicates the mean tested/control group $\mathrm{x} 100$

d) various doses of pure cell wall injected intravenously (i.v.) for 7 days. Statistical significance of difference from untreated control $* \mathrm{p}<0.01 \quad * \star \mathrm{p}<0.05$. 
Macrophages activity of peritoneal cells following multiple intraperitoneal injection of cell wall and fraction 2 of Eubacterium lentum.

The ability of cell wall and fraction 2 to augment macrophage activity was also assessed on day 14 after the initiation of cell wall and fraction 2 of Eubacterium lentum treatment, using P-815 mastocytoma and EL-4 lymphoma target cells by ${ }^{51} \mathrm{Cr}$ release assay (table 6). Percentage of cytotoxicity of PEC cells from mice treated with cell wall against P-815 and EL-4 target cells as E/T ratio of $10: 1$ was $17.0 \%$ and $16.3 \%$ respectively $(\mathrm{p}<0.01)$. and with fraction 2 treatment $22.3 \%$ and $15.8 \%$. Percentage cytotoxicity of PEC cells from mice treated with cell wall and fraction 2 at $\mathrm{E} / \mathrm{T}$ ratio of $10: 1$ was $17.0 \%$ and $15.8 \%$. Percentage cytotoxicity of PEC cells from mice treated with cell wall and fraction 2 at $E / T$ ratio of $5: 1$ was also significantly increased both against P-815 and EL-4 target cells compared with the untrated control group $(p<0.05)$. These results demonstrate that both intraperitoneal injection of cell wall and fraction 2 of Eubacterium lentum have the ability to augment the macrophages tumoricidal activity of peritoneal exudate cavity (PEC) cells in Balb/C mice.

Table 6. Macrophage activity of peritoneal exudate cavity (PEC) cells following treatment with cell wall and fraction 2 of Eubacterilum lentum.

\begin{tabular}{|c|c|c|c|c|}
\hline \multirow{3}{*}{ Group $^{\text {a) }}$ treatment } & \multicolumn{4}{|c|}{ cytostasis activity ${ }^{b}$} \\
\hline & \multicolumn{2}{|c|}{$\mathrm{P}-815^{\mathrm{c})}$} & \multicolumn{2}{|c|}{ EL-4 } \\
\hline & $10: 1^{d)}$ & $5: 1$ & 10:1 & $5: 1$ \\
\hline 1 control (untreated) & $4.5^{\mathrm{e}}$ & 9.8 & 4.6 & 5.9 \\
\hline 2 cell wall $(300 \mu \mathrm{g})$ & $17.0^{*}$ & $15.2^{\star \star}$ & $16.3^{\star}$ & $10.5^{\star}$ \\
\hline 3 fraction $2(1080 \mu \mathrm{g})$ & $22.3^{*}$ & $16.6^{\star \star}$ & $15.8^{*}$ & $13.8^{*}$ \\
\hline
\end{tabular}

a) Balb/c mice (5 mice/group) injected intraperitoneally with cell wall or fraction 2 for 7 days.

b) percentage of cytostasis activity measured by the ${ }^{51} \mathrm{Cr}$ release assay.

c) PEC cells collected on day 14 and cultured with target P-815 mastocytoma or EL-4 lymphoma for 20 hours.

d) effector : target ratio.

e) mean of triplicate culture.

Statistical significance of difference from untreated control $\star p<0.01 \quad \star *<0.05$

Effects of cell wall and fraction 2 treatment on natural killer (NK) activity of spleen cells.

Based on the results shown in table 5 , doses of $300 \mu \mathrm{g}$ cell wall fraction used because at this dose we obtained reproducible results in the survival time of tumor bearing mice (about two fold as compared with control group).

As shown in table 7, the NK activity of spleen cells against YAC-1 lymphoma target cells was determined by intravenous multiple injections of cell wall or fraction 2 of Eubacterium lentum.

Cell wall and fraction 2 treatments significantly augmented the NK activity of spleen cells as compared with the untreated control group. Percentage cytotoxicity of NK cell by cell wall treatment was $63.1 \%$ (E/T $50: 1)$ and $49 \%$ (E/T $25: 1$ ) respectively.

These results suggest that both cell wall and fraction 2 of Eubacterium lentum have the ability to augment the NK activity of spleen cells in an animal experiment.

Table 7. Effects of cell wall and fraction 2 of Eubacterium lentum on Natural Killer (NK) activity of spleen cells.

\begin{tabular}{lcc}
\hline \multirow{2}{*}{ Group $^{\text {a) }}$ treatment } & \multicolumn{2}{c}{ cytostasis activity against YAC-1 } \\
\cline { 2 - 3 } & $50: 1^{\mathrm{c})}$ & $25: 1$ \\
\hline I control (untreated) & $45.5^{\mathrm{d})}$ & 28.7 \\
2 cell wall $(300 \mathrm{~g})$ & $63.1^{\star}$ & $49.0^{\star}$ \\
3 fraction 2 (1080 g) & $62.0^{\star}$ & $51.3^{\star}$ \\
\hline
\end{tabular}

a) $\mathrm{C}_{3} \mathrm{H} / \mathrm{He}$ ( 5 mice/group) injected intraperitoneally (i.v) three times with cell wall or fraction 2 on day $-5,-3$, and -1 .

b) percentage of cytotoxic activity measured by the ${ }^{51} \mathrm{Cr}$ release assay on day $\mathrm{O}$.

c) effector : target ratio.

d) mean of triplicate culture.

Statistical significance of difference from untreated control ${ }^{*} \mathrm{p}<0.01$.

Kinetics of systemic single injection of cell wall and fraction 2 on natural killer (NK) activity of spleen cells.

The cytotoxic effects of intravenous single injection of cell wall and fraction 2 were assessed by the ${ }^{51} \mathrm{Cr}$ release method deseribed in "Materials and Methods". The following experiments were performed to examine the kinetics of cellular cytotoxicity against the YAC-1 lymphoma cells. As shown in figure 1, spleen cell treated with cell wall showed the same pattern in both ratios of E/T 50:1 and 25:1. Spleen cells from untreated control mice showed percentage cytotoxicity of $34.6 \%$ (E/T $50: 1$ ) and $25.2 \%$ (E/T $25: 1$ ). In addition, cytotoxicity of spleen cells from mice treated with cell wall were markedly increased on day 1 and thereafter gradually decreased up to the level lower than that of untreated control. The treatment by frac- 
tion $2(1080 \mu \mathrm{g})$, significantly increased the percentage cytotoxicity as compared to the control group on day 1 and 3 (31.9 and $19.8 \%$ for E/T $50: 1$ and E/T $25: 1$ respectively).
In contrast to the kinetics of cell wall treatment, the cytotoxic activity of spleen cells by fraction 2 treatment was increased again on day 7 at ratios of both $50: 1$ and $25: 1$ (figure 2).

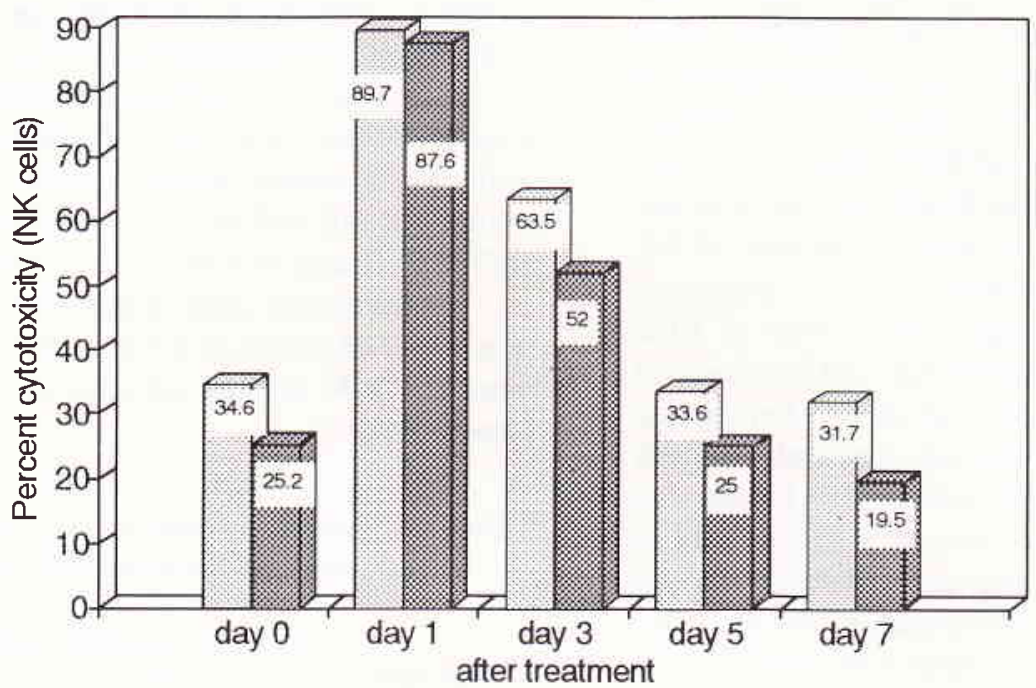

$E \pi$ T0:1

ET 25:1

Figure 1. Kinetics of Natural Killer (NK) acitivity of spleen cells treated with cell wall of Eubacterium lentum a) $\mathrm{C}_{3} \mathrm{H} / \mathrm{He}$ mice (5 mice/group) injected intravenously (i.v.) with pure cell wall $(300 \mu \mathrm{g} /$ mice) on day 0. b) cytotoxicity of spleen cells against YAC-1 lymphoma cells determined in a 4-hr ${ }^{51} \mathrm{Cr}$ release assay. c) cytotoxic activity indicated as the mean of triplicate culture.

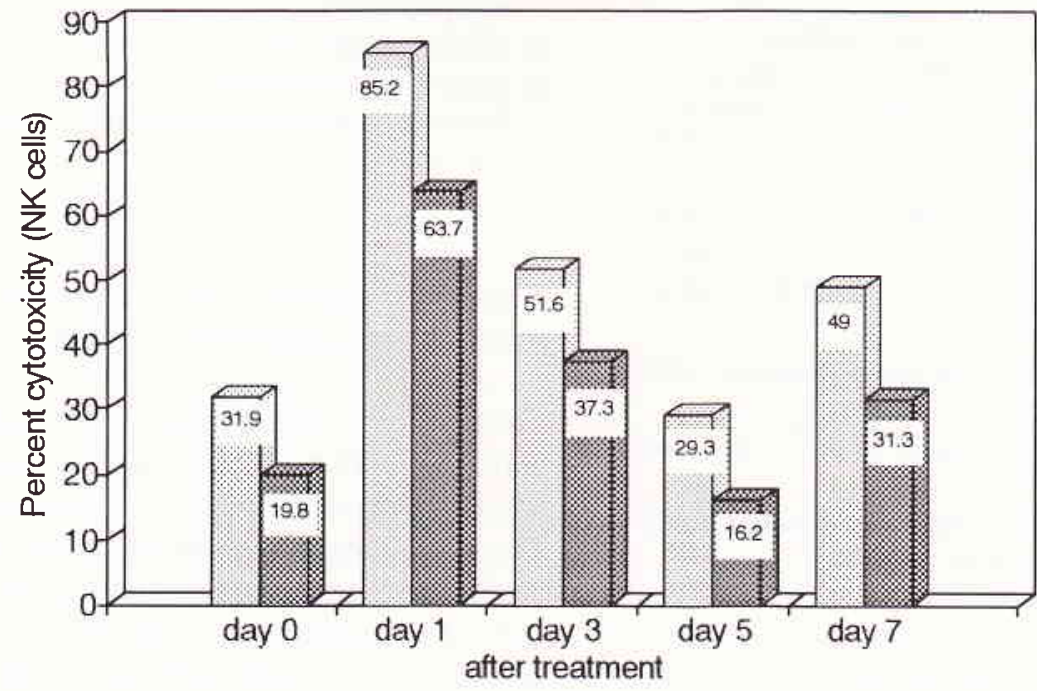

Figure 2. Kinetics of Natural Killer (NK) activity of spleen cells treated with fraction 2 of Eubacterium lentum a) $\mathrm{C}_{3} \mathrm{H} / \mathrm{He}$ mice (5 mice/group) injected intravenously (i.v.) with fraction 2 (1080 $\mu \mathrm{g} /$ mice) on day 0. b) cytotoxicity of spleen cells against YAC-1 lymphoma cells determined in a 4 -hr ${ }^{5 I} \mathrm{Cr}$ release assay. c) cytotoxic activity indicated as the mean of triplicate culture. 


\section{DISCUSSION}

The present study demonstrates that the antitumor effects of Eubacterium lentum fractions in Ehrlich ascites tumor-bearing mice are the consequences of a combination of sequential immunologic factors, leading to subsequent inhibition of Ehrlich ascites tumor cell growth and the long-term survival time of the animals. Halpern, et al ${ }^{18}$ reported that Corynebacterium parvum has a potent inhibition of Ehrlich ascites tumor growth by intraperitoneal injection, but intravenous treatment has not influenced significantly the mortality rate of mice and also that it is useful as an immunotherapeutic agent for patients with ascitic ovarian tumors. ${ }^{19}$ Bast, et $\mathrm{al}^{20}$ also reported that treatment with Corynebacterium parvum has inhibited the growth of human ovarian carcinoma and that it may prove useful for modulating the activity of human effector for antibody-dependent cell mediated cytotoxicity. In this study, we injected Eubacterium lentum or Eubacterium lentum fractions intraperitoneally (i.p) into ICR mice inoculated with Ehrlich ascites tumor i.p. The i.p. injection of Ehrlich ascites tumor cells resulted in subsequent growth of the tumor cells and the mice died from the tumor with increased peritoneal effusion (table 1). This finding suggests that this experimental model is suitable for studying exudation into the peritoneal cavity. Intraperitoneal injection of Eubacterium lentum, fraction 2 and cell wall following the inoculation of Ehrlich ascites tumor cells into ICR mice has significantly prolonged the survival time of mice and intratumoral treatment with fraction 2 or cell wall of Eubacterium lentum following subcutaneous (s.c.) inoculation of the solid form of Ehrlich ascites tumor cells also significantly prolonged the survival time (table 2). Treatment with cell wall was as effective as that with Eubacterium lentum when the agents were injected i.t. Furthermore, we examined the effects of intravenous injection of Eubacterium lentum fraction. Both fraction 2 and cell wall significantly inhibited the tumor growth as effective as Eubacterium lentum whole body.

We also observed a dose dependency of effects of cell wall fraction by local or systemic treatment on Erhlich ascites tumor-bearing mice. Our present study indicates that i.t. injection of cell wall with doses higher than $100 \mu \mathrm{g} /$ mouse was effective in inhibiting the tumor growth (table 4) and i.v. injection of cell wall with doses higher than $200 \mathrm{ug} /$ mouse significantly prolonged the survival time of mice (table 5).

It has been reported that the role of macrophages in vitro as effector cells was responsible for killing tumor cells and that this effect was augmented by Corynebacterium parvum treatment. ${ }^{21}$ In the experi- ments reported here, effector cells which appeared in mouse peritoneal exudate cavity after intra peritoneal injection of cell wall or fraction 2 of Eubacterium lentum were examined by the ${ }^{51} \mathrm{Cr}$ release assay. We observed that i.p. treatment of cell wall and fraction 2 have the ability to inhibit the growth of Ehrlich asertes tumor in ICR mice. Although the mechanism responsible for the inhibition of tumor growth was not clarified, we considered that the activated peritoneal macrophages induced by i.p. injected cell wall or fraction 2 of Eubacterium lentum released some mediator such as cytotoxic factor (CTF), and that mediators activated the peritoneal macrophages, resulting macrophages of Kupffer cells were activated by treatment with Lactobacillus casei and Corynebacterium parvum. ${ }^{22}$ We determined the cytolytic activity of peritoneal macrophages from mice injected with cell wall or fraction 2 of Eubacterium lentum i.p. and found that it was augmented by treatment with cell wall or fraction 2 of Eubacterium lentum (table 6). These results suggest that the ability of peritoneal macrophages to exlude tumor cells was augmented by i.p. administration of cell wall or fraction 2, resulting in inhibited tumor growth in the peritoneal cavity.

It has been reported that NK cells induced by the treatment with bacteria such as Streptococcus pyogenes play an important role in killing tumor cells both in animal experiments and in humans. ${ }^{23,24}$ In this present study, we determined NK activity of spleen cells from mice systemically injected with cell wall and fraction 2 of Eubacterium lentum. NK activity of spleen cells were significantly augmented by cell wall and fraction 2 of Eubacterium lentum treatment (table 7). These results suggest that NK activity of spleen cells play a key role in killing tumor cells in vitro. We also observed that the kinetics of cytotoxic activity of spleen cells from mice treated with cell wall are different from mice treated with fraction 2 . The cytotoxic activity of spleen cells from mice treated with cell wall was decreased on day 5 to day 7 following treatment (figure 1), but when treated with fraction 2 the cytotoxic activity increased again on day 7 after treatment (figure 2). In conclusion, NK activity of spleen cells induced by i.v. administration of cell wall or fraction 2 of Eubacterium lentum should also be expected to play an important role in destroying tumor cells.

\section{Acknowledgements}

I am extremely grateful to Dr.K. Kawai for his advice and manuscript review and to Dr.T.Hayashi for financial support through a grant from JIMA. 


\section{REFERENCES}

1. Sakamoto K, Konishi K. Antitumor effect of Normal Intestinal Micro flora on Ehrlich Ascites Tumor. Jpn J Cancer Res (Gann) 1988; 79: 109-16.

2. Morinaga S, Sakamoto K, Konishi K. Antitumor Activity and Its Properties of Eubacterium lentum. Jpn J Cancer Res (Gann) 1988; 79: 117-24.

3. Araki Y, Nakatani T, Nakayama K, Ito E. Occurence of N-Nonsubstituted Glucosamine Residues in Peptidoglyean of Lysozyme-resistant Cell Walls from Bacillus cereus. J Biol Chem 1972; 247: 6312-22.

4. Knox KW, Brandsen J. The isolation of Components from the Cell Wall of Lactobacillus casei. Biochem J 1962; 85: 15-23.

5. Sato K, Saito H, Tomioka H, Yokokura T. Enhancement of Host Resistance a gainst Listeria Infection by Lactobacillus casei : Efficacy of Cell Wall Preparation of Lactobacillus casei. Microbiol Immunol 1988; 32: 1189-200.

6. Azuma I, Taniyama T. Yamawaki M, Sugimura K, Yamamura Y. Adjuvant and antitumor activities of Nocardia cell-wall skeletons. Gann 1976; 7: 733-6.

7. Beller DI, Kielly JM, Unanue ER. Regulation of Macrophage Populations. I Preferential Induction of Ia-Rich Peritoneal Exudates by Immunologic Stimuli. J Immunol 1980; 124: 1426-32.

8. Nibbering PH, Van Der Heide GA, Van Furth R. Immunocytochemical analysis of cellular responses to BCG. Clin exp Immunol 1989; 75: 147-54.

9. Whiteside TL, Herberman RB. Short Analytical Review. The Role of Natural Killer Cells in Human Disease. Clin Immunol Immunopathol 1989; 53: 1-23.

10. Bonavida B, Jewett A. Activation of Human Peripheral Blood-Derived Monocytes by OK-432 (Streptococcus pyogenes): Augmented Cytotoxicity and Secretion of TNF and Synergy with rIFN-r. Cell Immunol 1989; 123: 373-83.

11. Kato I, Yokokura T, Mutai M.Macrophage Activation by Lactobacillus casei in Mice. Microbiol Immunol 1983; 27 : 611-8.

12. Yasumoto K, Manabe H, Ueno M, et al. Immunotherapy of Human Lung Cancer with BCG Cell-Wall Skeleton. Gann 1976; 67: 787-95.

13. Minagawa $\mathrm{H}$, Kobayashi $\mathrm{H}$, Yoshida $\mathrm{H}$, et al. Intratumoral induction of tumor necrosis factor by systemic administra- tion of Bordetella pertussis vaccine. Br J Cancer 1990; 62 372-5.

14. Ogura T, Namba N. Hirao F, et al. Association of Macrophage Activation with Antitumor Effect on Rat Syngeneic Fibrosarcoma by Nocardia rubra Cell Wall Skeleton. Cancer Research 1979; 39: 4706-12.

15. Chapes SK, Haskill S. Synergistic Effect between Neutrophil and Corynebacterium parvum in the Process of Macrophage Activation. Cancer Research 1984; 44: 31-4.

16. Pringle AT, Cummins CS, Bishop BF, Viers VS. Fate of Vaccines of Propionibacterium acnes After Phagocytosis by Murine Macrophages. Infection Immunity. 1982; 38: 371-4.

17. Azuma I, Ribi EE, Meyer TJ, et al. Biological active components from mycobacterial cell walls. I. Isolation and composition of cell wall skleton and component $\mathrm{P}^{3}$. J Natl Cancer Inst 1974; 52: 95-101.

18. Halpern BN, Biozzi G, Stiffel C, et al. Inhibition of Tumor Growth by administration of Killed Corynebacterium parvum. Nature 1966; 212: 853-4.

19. Mantovani A, Sessa C, Peri G, et al. Intraperitoneal administration of Corynebacterium parvum in patient with ascitic ovarian tumors to Chemotherapy : Effects on cytotoxicity of tumor-associated macrophages and NK cells. Int J Cancer 1981; 27: 437-46.

20. Bast RC Jr, Berek JS, Obrist R, et al. Intraperitoneal Immunotherapy of Human Ovarium Carcinoma with Corynebacterium parvum. Cancer Res 1983; 43: 1395-401.

21. Reynolds CW, Brunda MJ, Holden HT, Herberman RB Role of Macrophages in Invitro Augmentation of Rat, Mouse, and Human Natural Killer Activities. J Natl Cancer Inst 1981; 66: 837-42.

22. Hashimoto S, Seyama Y, Yokomura T, Mutai M. Cytotoxic factor production by Kupffer cells elicited with Lactobacillus casei and Corynebacterium parvum. Cancer Immunol Immunother 1985; 20: 117- 21.

23. Reynolds CW, Fukui H. Antitumor Activity of Streptococcus pyogenes Preparation (OK-432). I. Sequential Effector Mechanisms Following a Single OK-432 Injection in F344 Rats Leading to the Rejection of Syngeneic MADB 106 Tumor Cells. J Nat Cancer Res 1987; 79: 1011-7.

24. Uchida A, Mickshe M. Intrapleural administration of $\mathrm{OK}$ 432 in Cancer patients : Activation of NK cells and reduction of suppressor cells. Int J Cancer 1983; 31: 1-5. 